\title{
ХАРАКТЕРИСТИКА ПРАВООТНОШЕНИЙ В УСЛОВИЯХ ВОЕННОГО ПОЛОЖЕНИЯ
}

\begin{abstract}
Аннотация: Предметом данного исследования являются общественные отношения, возникающие в условиях военного положения. Изучаются понятие правоотношения, его структура. Отдельно анализируются все элементы данного правоотнотения: участники (субъекты), объекты и содержание правоотношения. Компетенции и полномочия органов государственной власти, их правосубъектность. Возможность ограничения субъективных прав и свобод граждан в условиях военного положения. Необходимость ограничения правосубъектности физических и юридических лии. Обосновывается возможность возложения дополнительных обязанностей на участников правоотношений военного положения. Анализируются правосубъектность органов государственной власти 8 современной Франиии и Великобритании. Проводится сравнение полномочий органов исполнительной власти в условиях военного положения. В основе исследования используются: общенаучные методы познания-философский, анализ, дедукиия историко-политический; а также частно-научные методы функииональный. сравнительноправовой, имоделирования. Вырабатываются общие принципы и приемы к изучаемомуявлению. Обосновывается необходимость правового прогнозирования и моделирования возможного вектора развития общественных отношений и необходимость предвидения правового регулирования общественных отномений в условиях режима военного положения.Сформулировано требование о необходимости предусмотреть дополнительные полномочия для органов государственной власти на период правоотношений в условиях военного положения, т.е. расширение их специальной правосубъектности. Высказана гипотеза о возможном растирении юридических обязанностей субъектов правоотношений в условиях военного положения. Использованы философские, общенаучные и частнонаучные методы познания, включая анализ, историко-политический, дедукиия, функииональный и сравнительный. Выработаны принципы и подходы к изучению правоотномений в условиях военного положения. Обосновывается структура правоотношений военного положения, состоящая из субъектов, объектов и содержания. В связи с чем выдвигается гипотеза о допустимости ограничения субъективных прав и возложения дополнительных обязанностей на участников данных правоотношений.Установлена необходимость установления дополнительных полномочий для органов государства в целях наделения их специильной правосубъектностью.Сформулировано положение о комплексном объекте правоотношений, возникающих в условиях режима военного положения.
\end{abstract}

Ключевые слова: Военное положение, правоотночение, правосубъектность, объекты, субъектыл, содержание, компетенция, сравнительный анализ, ограничения, обязанности.

Abstract: The subject of this research is the social relations that form in the conditions of martial law. The author examines the concept of legal relations and its structure, as well as separately analyzes all elements of it: participants (subjects), objects, the content of the legal relation, authority of the branches of government, their legal competency, ability to limit the subjective rights and liberties of citizens during martial law, as well as the need to restrict the legal rights of individuals and legal entities. The author justifies the ability to impose additional responsibilities upon the sides of legal relations during martial law. Analysis is conducted on the legal personality of the branches of government authority in modern France and Great Britain. The author substantiates the structure of legal relations of martial law, which consists of subjects, objects, and content, due to which the author proposes the hypothesis on permissibility of limiting the subjective rights and imposing additional responsibility upon the participants of these legal relations.

Keywords: Martial law, Legal relations, Legal personality, Objects, Subjects, Content, Competency, Comparative analysis, Restrictions, Responsibility.

елью правового режима военного положения как специального правового регулирования специфических общественных отношений с помощью комплекса правовых средств, является достижение правопорядка необходимого для нормального функционирования общества и государства. Такая цель достигается, в том числе, через установление взаимных прав и обязанностей участников этих отношений, т.е. через правоотношения.

Правоотношение, будучи итогом реализации юридической нормы, представляет собой вместе с тем и конкретное общественное отношение, облеченное в правовую форму. Сочетание указанных моментов ключ к пониманию места правоотношения в системе 
правового регулирования. Научная ценность понятия правоотношения, одна из главных его функций - раскрыть эффективность права в его неразрывной связи с регулируемыми им общественными отношениями. Процесс реализации нормы раскрывается наиболее полно тогда, когда из сферы долженствования мы переходим в сферу действительности. Закономерность соответствия формы правоотношения и его содержания выражается в том, что норма должна правильно отразить объективные требования, предъявляемые данным содержанием к его форме. Если эти требования достаточно глубоко познаны, правильно переведены на язык правовых категорий, согласованы с другими взаимосвязанными формами, правовая норма создает адекватную модель формы общественного отношения. ${ }^{1}$ Задачей правового регулирования военного положения является возможность на основе объективных закономерностей и прогнозируемой динамики таких отношений предусмотреть в правовой норме перспективы их развития, способствовать реализации своей внешней функции - обороны государства от нападения извне.

Правоотношения, которые могут возникнуть в условиях военного положения предметом изучения юриспруденции и особенно общей теории права еще не изучались и не моделировались. Имеющиеся научные исследования отечественных ученых затрагивают лишь некоторые специфические сферы отношений в условиях особых режимов, касающиеся действующего законодательства, объема и пределов ограничения прав и свобод, историческому анализу нормативного регулирования или юридической ответственности в условиях военного, особого или чрезвычайного режима. Недостаточный уровень разработанности этой темы объясняется тем, что ученые крайне неохотно исследуют общественные отношения, которые могут возникнуть в условиях правового режима военного положения, так как трудно спрогнозировать возможный вектор их развития, и соответственно насколько эффективно будет функционировать созданная ими модель правового регулирования таких отношений.

Закрепляя в законодательстве сложившиеся или складывающиеся общественные отношения, государство стремиться создать благоприятные условия для формирования или появления новых социальных отношений. В юридической науке, в целом считается, что нормы права не ставят перед собой цели формирования

${ }^{1}$ Халфина Р.О. Общее учение о правоотношении. М., Юр.лит., 1974. C. 34 относительно новых, самостоятельных видов общественных отношений, а выступают в качестве предпосылок для закрепления фактических отношений. ${ }^{2}$ Вместе с тем следует признать, что в ряде случаев, например, нормы конституционного и иных отраслей права, закрепляя и регулируя существующие общественные отношения, создают тем самым условия для дальнейшего развития данных и зарождения на их основе новых общественных отношений.

Исследуемые нами общественные отношения в условиях военного положения в современной России, как и большинства государств, в которых они предусмотрены, еще не возникали, поэтому нормы права, содержащиеся в формах права о военном положении, при определенных условиях, моделируют лишь возможный вектор регулирования, впервые складывающихся общественных отношений.

Данные правоотношения характеризуются общеизвестной структурой, в которой предполагаются специфические особенности деятельности и статуса субъектов, крайне сложной спецификой их содержания, разнообразием объектов правового воздействия.

Субъектом этих правоотношений будут являться все физические, юридические лица, органы государственной власти, включая органы военного управления, органы местного самоуправления и их должностные лица, которые на основе правовых норм, будут являться участниками анализируемых правоотношений.

Как известно, субъект правоотношения - это участник правоотношений, который в соответствие с нормами права является носителем субъективных прав и обязанностей. Шершеневича Г.Ф. рассматривает субъект права как «тот, кому объективное право присваивает в юридическом отношении субъективное право. Присвоение права субъекту заключается в том, что только ему дано осуществление интереса, обеспеченного нормами права, только от его воли зависит привести в движение социальный аппарат, обеспечивающий интересы» $\rangle^{3}$. И в тоже время предписанные нормы права полностью утрачивают свою силу по отношению к субъектам права, если таковых не имеется. Таким образом, правоотношения имеют свой смысл только при наличии субъекта права, иначе их просто некому будет приводить в жизнь и они так и останутся в форме абстрактных предписаний.

${ }^{2}$ Марченко М.Н. Проблемы Теории Государства и Права. М.,2001. C. 638

${ }^{3}$ Шершеневич Г.Ф. Общая теория права. Вып. III. 1010. С.872. Хропанюк В. Н. Теория государства и права. Хрестоматия. Учебное пособие. М., 1998. 944 с. 
DOI: $10.7256 / 1811-9018.2015 .8 .12562$

При цитировании этой статьи сноска на доі обязательна

\section{Право и политика 8 (188) • 2015}

В условиях исследуемых правоотношений военного положения, основным субъектом будут выступать органы государства, включая органы военного управления, которые должны обладать правосубъектностью, т.е. способностью иметь юридические права и обязанности и осуществлять их посредством своих действий. Наличие специфических властных полномочий у этих органов, наделение их необходимым специальным статусом, предполагает наличие у них дополнительных прав, обязанностей и ответственности в соответствие с действующим законодательством. Представляется, что перечисленные выше субъекты на момент наступления таких общественных отношений, которые предусматриваются нормами права, уже должны обладать соответствующими полномочиями и компетенциями. Как это обстоит в действительности на примере Российской Федерации можно увидеть из анализа содержания действующего законодательства о военном положении. Так, глава III. «Полномочия органов государственной власти в области обеспечения режима военного положения и особенности их функционирования в период действия военного положения» ${ }^{4}$ в ст.11 наделяет Президента правом утверждать положения о федеральных органах исполнительной власти, руководство которыми он осуществляет. Действующий Указ Президента Российской Федерации от 09.03.2004 N 314 (ред. от 22.06.2010) «О системе и структуре федеральных органов исполнительной власти», ${ }^{5}$ а также положения о соответствующих федеральных органах исполнительной власти не содержат перечень таких полномочий в условиях военного положения. Это означает, что в период, когда будет крайне важным взвешенное, оперативное, компетентное решение возникающих задач органами государства, они будут заняты изучением этого законодательства с целью составления проектов нормативных правовых актов по вопросам своих компетенций в указанном правовом режиме, их согласованием и принятием. О качестве таких нормативных правовых актов, их соответствие духу Конституции и законам можно только догадываться. Отсутствие соответствующих полномочий у органов государства на такой период времени наблюдается на примере органов внутренних дел. В п. 34 ст.12 «Положении о Министерстве Внутренних Дел Российской Федерации», ${ }^{6}$ упоминается лишь об «участии в обеспечении режима военного положения и режима чрезвычайного положения в случае их введения

\footnotetext{
${ }^{4}$ ФКЗ «О военном положении». N 1-ФКЗ. 2002г.

${ }^{5}$ Собрание законодательства РФ. N 11. 15.03.2004. Ст. 945.

${ }^{6}$ Собрание законодательства РФ. 07.03.2011. N 10. Ст. 1334.
}

на территории Российской Федерации или в отдельных ее местностях, а также в проведении мероприятий военного времени и мероприятий в рамках единой государственной системы предупреждения и ликвидации чрезвычайных ситуаций». Следует признать, что данная формулировка не называет ни одного мероприятий, ни говоря о перечне, которыми должны наделяться органы внутренних дел в условиях военного положения, а это задача правотворческого органа, которая должна быть реализована до наступления указанных обстоятельств. Так, из истории известно, что только через два года после начала войны, в начале 1943 г. был издан приказ Народного Комиссара Обороны СССР «Об упорядочении работы по эвакуации военнопленных с фронта» № 001 от 2 января 1943г., ${ }^{7}$ в котором обращалось внимание на несогласованность действий командиров Красной Армии и войск НКВД по эвакуации пленных, что приводило к их гибели. Содержание такого приказа можно было бы предусмотреть заранее, хотя оправданием является тот факт, что до этого времени не было такого значительного количества немецких пленных. Конечно, аналогия осуществления властных полномочий, наделения ими соответствующих органов государства в условиях тоталитарного режима может показаться неуместной, но этим подчеркивается актуальность и значимость того, что в условиях соответствующих режимов возникала крайняя необходимость правового регулирования специфических общественных отношений, в связи с чем создавались пусть и поздно, специальные субъекты- органы государства по содержанию военнопленных. Иными словами, необходимо заранее предвидеть необходимость создания соответствующих органов государства, либо наделить специальной правосубъектностью существующие, включающую конкретные полномочия по решению задач, возникающих вследствие осуществления режима военного положения.

Такой вывод подтверждается практикой многих государств мира. Осуществление чрезвычайных функций в этих государствах самым непосредственным образом связано с изменениями в деятельности аппарата управления и принуждения. Такие изменения предполагают значительное увеличение объема полномочий исполнительных органов государственной власти и заметный рост части государственного механизма. Поэтому правовые режимы военного, чрезвычайного положения в них отнесены к сфере

\footnotetext{
${ }^{7}$ Цитируется по книге: Приказы народного комиссара обороны CCCР. 1943 - 1945 гг. М.: Терpa, 1997. Т. 13456 с.
} 
административного права, или административного регулирования. Например, одним из основных последствий введения осадного положения во Франции является передача власти гражданской администрации органам военного управления, на которые возлагается ответственность за общее руководство обороной. В тоже время гражданские органы государственной власти должны осуществлять те полномочия, от которых отказываются военные. Введение осадного положения связано со значительным расширением полномочий военных властей, которым предоставляется возможность: проводить обыски жилых помещений в ночное время; удалять ранее многократно судимых и бездомных граждан в места, отведенные на случай осадного положения; предписывать сдачу оружия и боеприпасов, проводить их розыск и изъятие, запрещать публикации и собрания, которые подстрекают к беспорядкам или способны их повлечь. При осуществлении режима осадного положения возможно расширение юрисдикции военной юстиции с соответствующим сокращением компетенции общих судов. На нее возлагаются функции проведения расследования ряда преступлений, таких как покушения, заговоры, неповиновение, убийства, посягательства на индивидуальную свободу, подделка государственных печатей, разрушение зданий, бандитизм и ряд иных. И в целом судебная практика признает во время войны за административными органами более широкие полномочия, чем во время мира. ${ }^{8}$

В подобных условиях Государственный совет (фр. Conseil d'État - орган французского правительства, призванный подавать свои мнения по вопросам, подлежащим непосредственному разрешению верховной власти) допускает возможность в определенные периоды кризиса администрации нарушать законность. Если применение закона невозможно, то администрация действует вопреки закону. Исключительный характер ситуации устанавливается самой администрацией и подлежит судебному контролю. Особым статусом наделяются военные коменданты, которым закон об осадном положении 1849г., дает возможность вводить самим осадное положение, о чем они должны немедленно сообщить Правительству. Значительными полномочиями наделяются префекты регионов, в соответствие с Ордонансом от 7 января 1959г. «Об общей организации обороны», они осуществляют общую координацию всех органов власти, за исключением судебных, руко-

${ }^{8}$ Пилипенко А.Н. Институты чрезвычайного режима во Франции.// Право и экономика. 1007. №7-8.С.106. водят работой полиции, осуществляют реквизиции, председательствует в Комитете обороны, в который включены командующие видами вооруженных сил, находящихся в пределах департамента.

В отличие от континентальной системы права, для которой характерно наделение исполнительной власти собственными чрезвычайными правами, в Великобритании процедура наделения органов исполнительной власти указанными полномочиями осуществляется их делегированием парламента на усмотрение правительства. В период осуществления подобного правового режима правительство имеет право издавать значительное число постановлений, приказов и инструкций, обладающих силой закона, которые в ряде случаев оформлялись в целые сборники актов, включавшие в себя до 30 и более чрезвычайных постановлений.

Великобритании до войны 1914 года знала только военное положение по «общему праву», т.е. основанному на судебных прецедентах и рассматривалось как фактическая диктатура исполнительной власти, во время которой «silent leges» (молчат законы). Закон 8 августа 1914г. наделил исполнительную власть правом издавать указы в целях обеспечения общественной безопасности и защиты королевства. Так компетентные органы наделяются правом производить конфискацию земли, движимого и недвижимого имущества, которое будет сочтено «необходимым или целесообразным», при этом размер компенсации за реквизированное имущество определяется арбитром, назначаемым лорд-канцлером. Государственный секретарь наделяется правом контролировать добычу нефти, угля и газа, лимитировать их потребление, а также продовольствия и электроэнергии. Так называемые кодексы чрезвычайных постановлений (1926, 1966 и 1970) предоставляют право органам исполнительной власти отступать от своих обязанностей по снабжению населения и предприятий газом и электроэнергией, если, по мнению государственного секретаря, возникнет необходимость экономии, консервирования и лучшего использования топливных ресурсов (Regs. 17,18. EM 1972). На период действия прокламации о чрезвычайном положении министр транспорта наделяется правом отдавать распоряжения о недопущении какого либо судна, либо класса судов для регулирования передвижения, погрузки и разгрузки судов или для установления их приоритетов: министр связи - прерывать почтовую и телеграфную связь. Приведенные примеры наделения дополнительными полномочиями органов государ- 
DOI: $10.7256 / 1811-9018.2015 .8 .12562$

При цитировании этой статьи сноска на доі обязательна

\section{Право и политика 8 (188) 2015}

ственной власти, прежде всего исполнительной не являются исчерпывающими. ${ }^{9}$

Аналогичным образом поступает законодательство США. Прокламация о введении режима чрезвычайного (военного) положения должна содержать полномочия соответствующих государственных органов и должностных лиц. Изменяется порядок деятельности и формы взаимодействия органов исполнительной власти на всех трех уровнях власти - федерации, штатов, местных органов власти. Координирующую роль в условиях чрезвычайного положения принадлежит Федеральному агентству по вопросам управления в чрезвычайных обстоятельствах, которое разрабатывает программы предотвращения кризисных ситуаций и ликвидации последствий, формы взаимодействия органов государственной власти. Дополнительными полномочиями и преференциями наделяются многие органы государственной власти. Например, Закон 1951 г. о гражданской обороне, предполагает освобождение Правительства от ответственности за смерть или увечье, причиненные лицам, работающим по найму. В этот период приостанавливается действие целого ряда норм административного производства, обеспечивающих процессуальные права граждан и юридических лиц. ${ }^{10}$

Исходя из того, что значительная часть органов государственной власти законодательством напрямую не привлекаются к осуществлению режима военного положения, тем не менее, прогнозирование развития этих правоотношений, позволяет предположить их участие. Это коснется, прежде всего, тех органов государства, которые осуществляют государственную власть в таких сферах как: здравоохранение, трудовая деятельность, социальная защита, экономика, охрана природы и недропользования, энергетика, средства связи и коммуникации и других.

Несмотря на то, что основным субъектом изучаемых правоотношений выступают органы государства, на которые возлагаются соответствующие функции и задачи, следует отметить, что не менее значимым субъектом в них останутся граждане (физические лица) и их объединения, юридические лица. В правовом регулировании специфических общественных отношений военного положения им отводится значительная

\footnotetext{
9 Домрин А.Н. Правовые институты чрезвычайного режима в Великобритании.//Зарубежное законодательство. 1996. № 15-16. C.83-90.

${ }^{10}$ Касаткина Н.М., Лафитский В.И. Правовые институты чрезвычайного режима в США.//Право и политика.1996. №12. С.76.
}

роль, которую они будут осуществлять, прежде всего, в сферах частного права. Некоторые из них, например, воинские части будут выступать одновременно участниками нескольких правоотношений. Командиры этих частей будут выполнять исполнительно-распорядительные, то есть административные функции на территориях, где введен режим военного положения, а также выполнять функции, не свойственные им в мирное время. Например, российское законодательство возлагает на них:

- выдачу доверенностей, приравненных к нотариальным (ч.2 ст.185 ГК РФ);

- удостоверение завещаний (ст.1127 ГК РФ) и подписей (ст.13 Ф3 2008г. «Об опеке и попечительстве»);

- заявление о смерти (ст. 66 Ф3 1997г. «О записи актов гражданского состояния»); и другие.

Они же будут выступать субъектами гражданских правоотношений (юридическими лицами), участвуя в имущественных отношениях, связанных с заключением договоров на обеспечение себя различного рода довольствием от продовольственного, до банно-прачечного (при сохранении, на примере вооруженных сил России, аутсорсинга).

Следует предположить, что в исследуемых правовых режимах правосубъектность иных участников правоотношений будет значительно ограничена. И прежде всего речь идет о широком ограничении субъективных прав граждан и юридических лиц.

Под субъективным правом следует понимать принадлежащую управомоченному субъекту в целях удовлетворения его интересов индивидуальноконкретную, властную меру (вид, объем и т.п.) дозволенного (возможного) поведения, обеспеченную соответствующими юридическими обязанностями других участников правоотношений, а также средствами и методами экономического и политического, организационного и идеологического, нравственного и юридического, технического государственного и негосударственного воздействия.

Не вдаваясь в рамках проводимого исследования в анализ существующих концепций природы субъективного права (от формально-логического до социологического и этического) следует отметить, что введение режима военного положения, как правило, сопровождается ограничением либо приостановлением всех или основных гражданских прав и свобод.

По законодательству ряда государств, как отмечалось выше, это означает временное приостановление гарантий личной неприкосновенности и неприкосновенности жилища; ужесточение уголовной и адми- 
нистративной ответственности при одновременном упрощении процедуры судопроизводства, проведения обысков, арестов и задержаний, признание досудебных заявлений подсудимого в качестве доказательства его вины; применение различных средств принуждения; ограничение свободы слова, включая свободу печати и информации, а также тайны переписки, свободы собраний, митингов, шествий и демонстраций, свободы объединений, права на проведение забастовок, свободы выбора места жительства и передвижения, экономических прав и свобод, выбора и занятия профессией, наложения гражданских обязанностей и повинностей. Нельзя отрицать того факта, что абсолютных прав личности не существует. В противном случае каждый становится судьей своих собственных прав и обязанностей, что немыслимо при условиях проживания личности в обществе, следовательно, речь должна идти об установлении границ реализации субъективных прав. Позитивное право, устанавливая рамки юридической возможности деятельности людей, всегда ограничивает их независимость, заменяя ее закрепленной в законодательстве свободой. Обретая законодательное выражение, права человека получают дополнительную «энергию», а государство, законодательно закрепляя их, обязывает себя гарантировать и обеспечивать права и свободы. По мнению А.В. Малько, ${ }^{11}$ ограничение прав человека является острой проблемой для любой страны, так как такие действия со стороны государства являются цивилизационным способом регулирования меры свободы индивида в обществе в определенных ситуациях. Основным предназначением правовых ограничений (как установленных законом изъятий из правового статуса гражданина, носящих превентивный характер) является, прежде всего, не ущемление, а сужение свободы.

По мнению ряда ученых ${ }^{12}$ при рассмотрении проблемы ограничения прав важно иметь в виду, что речь идет не об ограничении свободы (или равенства и справедливости) как содержания того или иного права, а об ограничении условий и пределов реализации этой свободы в данной сфере общественной жизни. Следовательно, по их мнению, ограничивается не сама свобода как благо, предоставляемое тем или иным правом, а продолжительность, полнота и качество пользования ею. Такой взгляд, бесспорно, заслужива-

${ }^{11}$ См.: Малько А.В. Стимулы и ограничения в праве. М., 2003. C.102, 105.

${ }^{12}$ Беломестных Л.Л. Ограничение прав человека. М., 2003. С. 8, 9. ет внимания на природу ограничений субъективных прав, но с позиции позитивизма ограничение «содержания» субъективного права, по нашему мнению, и выражается в условиях и пределах (временных, пространственных, субъектных и иных) этого права. Такого же взгляда придерживаются составители ряда словарей, например, большой юридический энциклопедический словарь, определяет «ограничения» как вытекающие из законов и других нормативных актов, из решений государственных органов пределы, границы, за которые не должна выходить деятельность субъектов. ${ }^{13}$ В целом на сегодняшний день вопросы ограничения субъективных прав и свобод только в последние десятилетия отечественной науке исследовались неоднократно, ${ }^{14}$ поэтому предметом данного исследования не являются.

В то же время правосубъектность юридических и прежде всего физических лиц в условиях отношений, возникающих при осуществлении правового режима военного положения, будет характеризоваться установлением со стороны государства дополнительных юридических обязанностей, которые необходимы для осуществления им своего права на защиту от нападения извне.

Юридические обязанности, как элемент содержания правоотношений, в том числе, возникающих в условиях военного положения - это установленные и гарантированные государством требования к поведению человека, органов государства, должностных лиц, это официальная мера должного поведения.

Функциональное назначение юридических обязанностей - корреспондировать субъективным правам, выполнять свою часть работы в общем механизме правового регулирования, направлять деятельность субъектов в нужное русло; а также - формировать правосознание

${ }^{13}$ Барихин А.Б. Большой юридический энциклопедический словарь. М., 2003. С. 391. Ожегов С.И., Шведова Н.Ю. Толковый словарь русского языка. М.: Азбуковник, 1999. С. 444.

${ }^{14}$ Лопаева В.В. Проблема ограничения прав и свобод человека и гражданина в конституции Российской Федерации //Журнал российского права. 2005. № 7. Пчелиниев С.В. Проблемы ограничения прав и свобод граждан в условиях особых правовых режимов. М., Норма, 2006. - С.480. Квитко А.Ф. Конституционно-правовые основы ограничения прав и свобод человека и гражданина в Российской Федерации. Автореф. дис.... канд. юрид. наук М., 2007. Принципы, пределы, основания ограничения прав и свобод человека по российскому законодательству и международному праву: Материалы «круглого стола» // Государство и право. 1998. № № 7, 8,10 . Эбзеев Б.С. Человек, народ, государство в конституционном строе Российской Федерации. М., 2005. С. 230. Ягофарова И.Д. Основные характеристики ограничения прав и свобод человека: теоретико-правовой аспект // Академический юридический журнал. 2002. № 4 и др. 
DOI: $10.7256 / 1811-9018.2015 .8 .12562$

При цитировании этой статьи сноска на ооі обязательна

\section{Право и политика $8(188) \cdot 2015$}

и правовую культуру, служить фактором укрепления законности и правопорядка. Юридические обязанности участников правоотношения режима военного положения обеспечивают использование своего субъективного права другим участником - государства на сохранение своего суверенитета в условиях военной агрессии и наоборот, обязанности предполагают чье-то право требовать их исполнения. Вне соотношения друг с другом данные категории немыслимы, они могут действовать только в «одной связке», а не порознь. Обязанности - обратная сторона прав. Принцип единства прав и обязанностей вытекает из международного права, из признания взаимной ответственности государства и гражданина, общества и личности.

В конституциях современных зарубежных стран обязанности представлены шире и значительнее. Существует точка зрения, что слишком большой перечень обязанностей - признак тоталитарного государства. Отчасти это так. В то же время без обязанностей не может обойтись ни одно «нормальное» общество, и объем их зависит от многих причин: национальных традиций, развитости демократии, уровня политической и правовой культуры и т.д. Обязанности, писал Цицерон ${ }^{15}$ - другой конец «демократической оси», обеспечивающей поддержание баланса интересов в обществе. Без этого невозможна сколько-нибудь упорядоченная жизнь людей.

В отличие от субъективного права от исполнения юридической обязанности нельзя отказаться. Представляется, что предусмотренные правом мирного времени обязанности граждан не будут являться исчерпывающими. С изменением общественных отношений, фактических обстоятельств, в ходе осуществления подобных режимов обязанности будут многократно увеличиваться и усиливаться как в количественном, так и в качественном выражении. В случае отказа или недобросовестного выполнения государство по собственной инициативе или по требованию другого участника правоотношения принудительно обеспечивает выполнение юридических обязанностей. В этом главное отличие обязанности от субъективного права, которое всегда реализуется добровольно, по свободному усмотрению субъекта.

На примере законодательства Российской Федерации ${ }^{16}$ видно, что в целях обеспечения обо-

\footnotetext{
${ }^{15}$ Цищероп. Об обязанностях. СПб. 1903.

16 Часть 1 ст. 59 Конституции Российской Федерации, Ч. 3 ст. 1 Федерального закона от 31 мая 1996г. N 61-ФЗ «Об обороне» // Российская газета от 6 июня 1996г. Федеральный закон от 28 марта 1998г. N 53-ФЗ «О воинской обязан-
}

роны страны устанавливаются следующие обязанности граждан:

а) воинская обязанность граждан;

б) военно-транспортная обязанность собственников транспортных средств, т. е. предоставление транспортного средства, находящегося в собственности, федеральным органам исполнительной власти;

в) предоставление в военное время для нужд обороны по требованию федеральных органов исполнительной власти зданий, сооружений, транспортных средств и другого имущества, находящегося в собственности;

г) запрет на доступ к сведениям, составляющим государственную тайну в области обороны;

д) выполнять требования, изложенные в полученных ими мобилизационных предписаниях, повестках и распоряжениях военных комиссариатов.

Отказ от исполнения юридической обязанности является основанием для юридической ответственности. Точно так же, как и субъективное право, юридическая обязанность является мерой поведения субъекта правоотношения. Мера - это те границы осуществления обязанности, которые предусмотрены в правовой норме. Выход за эти границы означает либо недобросовестное отношение к обязанности, либо злоупотребление, посягательство на субъективное право другого участника правоотношения. Являясь необходимым средством и компонентом воздействия на общественные отношения, без обязанностей невозможно представить эффективную правовую систему государства, в которой существует правопорядок как цель правового регулирования.

К сожалению, юридические обязанности в гораздо меньшей степени исследованы учеными, чем субъективные права. Соответственно эта категория слабее распространена в общественном и индивидуальном сознании - о них часто просто «забывают». Следовательно, исследование этого феномена - цель общей теории права и отраслевых юридических наук. «Люди, не ведающие своих обязанностей, писал И.А. Ильин, - не в состоянии и блюсти их; люди, по знающие своих полномочий, произвольно превышают их или же трусливо уступают силе; люди, не желающие признавать запретностсй, легко

ности и военной службе». // С3 РФ. 1998. № 13. Ст. 1475. ст. 13 Федерального закона от 26 февраля 1997 г. N 31-Ф3 «О мобилизационной подготовке и мобилизации в Российской Федерации»//Российской газете от 5 марта 1997 г. Положение о военно-транспортной обязанности. Утв. Указом Президента России от 2 октября 1998 г. // Российская газета. 1998. 
забывают всякий удерж и дисциплину, или оказываются обреченными на правовую невменяемость». ${ }^{17}$

Равновесное соотношение прав и обязанностей должно создавать такое отношение между личностью, обществом и государством, которое устроило бы всех. Следовательно, поиск взаимоприемлемого баланса прав и обязанностей участников правоотношений в условиях военного положения должен стать предметом не только практиков, но и представителей научного сообщества. Подготовить общество в целом и отдельного индивида в частности к тому, что носитель обязанности должен понимать и сознавать свою «несвободу» и связанность ради общего блага.

Специфическим и непростым является анализ объектов тех многообразных фактических отношений вообще и правоотношений в частности, которые могут возникнуть в условиях режима военного положения. Назначение понятия объект правоотношения состоит в том, чтобы раскрыть смысл существования правоотношения, показать, для чего субъекты вступают в правовое отношение и действуют в нем, реализуя свои права и обязанности. Проблема объекта правоотношения принадлежит к числу наиболее дискуссионных в теории права.

В теории права объект правоотношения обычно рассматривается в контексте анализа его структуры, несмотря на то, что, как указывают некоторые авторы, «объект», как таковой, элементом структуры правоотношения не является и вообще выходит за границы системного понимания правоотношения. ${ }^{18}$

Выдвигаются несколько подходов в понимании категории «объект». Один из общих аргументов, который используют большинство исследователей объекта правоотношения, - это традиционное философское понимание объекта, которое дает трактовку объекта в противопоставлении его субъекту и понимает под объектом нечто, на что направлена деятельность последнего. Так, сторонники признания свойств объекта правоотношения за материальными предметами окружающего мира трансформируют философское понимание объекта как: «предмета, на который направлена деятельность субъектов правоотношения, осуществляемая в процессе реализации ими своих юридических прав и обязанностей». ${ }^{19}$

\footnotetext{
${ }^{17}$ Ильин И.Л. О сущности правосознания. М., 1993. С. 24.

${ }^{18}$ Гражданское право: Учебник. В 2-х т. Т. 1 / Под ред Е.А. Суханова. М., 1993. С. 51-52; Гражданское право: Учебник. В 2-х т. Т. $1 /$ Под ред. Ю.К. Толстого, А.П. Сергеева. СПб., 1996. С. 77-79 и др.

${ }^{19}$ Дудин А.П. Объект правоотношения (вопросы теории). Саратов,
} 1980. C. 68.
В свою очередь, и сторонники «поведенческой» теории объекта правоотношения используют в своей аргументации те же философские посылки. В частности, О.С. Иоффе, аргументируя свою позицию, высказывается относительно роли объекта в правовой теории: «...не только в философии, но и в любой другой науке, рассматривающей вопрос об объекте определенного явления, под объектом понимают не то, по поводу чего это явление существует, а то, на что данное явление оказывает или может оказать воздействие». ${ }^{20}$

Таким образом, достижения философской науки равным образом используются в качестве одного из основных доводов в аргументации сторонников различных подходов.

Наибольшие различия в понимании категории объект правоотношения между различными теориями данного вопроса наблюдаются в области общей теории права. Так Р.О. Халфина, отмечает, что «под объектом понимаются реальные предметы материального мира, продукты духовного творчества в объективированной форме». Следует отметить, что такое понимание «объекта правоотношения» сопряжено с утверждением о тождестве содержания понятий объект права и объект правоотношения. ${ }^{21}$

Другая точка зрения на объект включает в это понятие не только предметы материального мира и продукты духовного творчества человека, но и сами действия людей, человеческое поведение. По мнению сторонников такой трактовки, правоотношение как общественная связь, устанавливающаяся между людьми в результате их взаимодействия, «может воздействовать только на поведение человека. Поэтому в качестве объекта гражданского правоотношения выступает поведение его субъектов, направленное на различного рода материальные и нематериальные блага. Например, В.Н. Хропанюк дает следующее определение: «Объект правоотношения - это то, на что воздействует правоотношение... объектом правоотношения является фактическое поведение его участников», поскольку «объектом» воздействия правовых норм является волевое поведение человека. ${ }^{22}$

Развернутое теоретическое обоснование точки зрения, в соответствии с которой единым н единственным объектом правоотношения является «человеческое поведение, деятельность или действия

\footnotetext{
${ }^{20}$ Иоффе О.С. Правоотношение по советскому гражданскому праву. Л., 1949. С. 81

${ }^{21}$ Халфина Р.О. Общее учение о правоотношении. М, 1974. С.214.

${ }^{22}$ Хропанюк В.Н. Теория государства и права. М., 1995. С. 313.
} 
DOI: $10.7256 / 1811-9018.2015 .8 .12562$

При цитировании этой статьи сноска на доі обязательна

\section{Право и политика 8 (188) 2015}

людей» дает О.С. Иоффе. ${ }^{23}$ Указывая на то, что непосредственное содержание гражданского правоотношения не сводится к поведению обязанных лиц, но формируется из правомочий и обязанностей, предоставленных участникам правоотношения, делается вывод о том, что объект правоотношения не имеет ничего общего с объектом, на который направляется поведение обязанных лиц, а вопрос «должен ставиться как вопрос об объекте правомочий и обязанностей, составляющих содержание правоотношения». Таким образом, автор устанавливает тождество объекта правомочий и обязанностей субъектов правоотношения с объектом правоотношения в целом.

Представляется, что почти каждая из названных теорий, выдвинутых в качестве объяснения категории «объект правоотношения», имеет в своем основании некоторые существенные посылки и рассуждения, с которыми трудно спорить как с общефилософских позиций, так и с точки зрения правовой теории.

Признавая более близкой к реальности исследуемых правоотношений плюралистическую теорию, объект правоотношения можно определить как явление внешнего мира, способное удовлетворить интерес управомоченного лица, выступающее в виде вещи, услуги, продукта духовного творчества или личного нематериального блага, ради которого и действуют субъекты правоотношения в рамках своих юридических прав и обязанностей.

Для общественных отношений, возникающих в условиях режима военного положения характерно то, что они регулируются нормами различных отраслей права (романо-германская правовая семья) и судебными решениями в различных сферах правоприменения (для стран общего права).

В силу этого объекты правоотношения будут характеризоваться многообразием их видов и разносторонностью. Представляется, что такими объектами будут выступать объекты, прежде всего конституционного права: государственная территория и её границы; личные неимущественные блага (жизнь, здоровье); материальные блага (природные ресурсы, средства государственной казны); поведение людей (переселение из мест военных действий, призыв на военную службу, трудовая повинность, митинги и т.д.); деятельность органов и должностных лиц государства, негосударственных организаций (прежде всего политических партий как легальных, так и нелегальных) и многое другое. Объектом таких правоотношений будут выступать объекты административного права: действия (решения) субъектов административного права, их положительное или негативное поведение. В сферу объектов правоотношения военного положения будут отнесены объекты гражданского права (вещи, иное имущество, в том числе имущественные права; работы и услуги; результаты интеллектуальной деятельности, нематериальные блага); уголовного: (общественно опасное деяние, запрещенное уголовным законом); трудового: (материальная заинтересованность в труде, конечный результат трудовой деятельности, социально-экономические блага, соответствующие требованиям работника и нанимателя) и иных отраслей права. Определение объекта правоотношений возможно не столько в общетеоретическом, сколько в прикладном плане, применительно к каждому конкретному случаю. Каждая отрасль имеют свои особые объекты правоотношений, свой собственный методологический подход к их определению.

Таким образом, широкий перечень объектов существующих в условиях военного положения показывает возможность возникновения множества видов правоотношений в исследуемом правовом режиме.

В связи с чем, представляется крайне важным попытаться «увидеть» те правоотношения, которые могут сложиться в условиях, прежде всего военного положения. Именно этот режим отличается многообразием возможных ситуаций, которые урегулировать в период его осуществления попросту будет некогда в силу стремительности, неожиданности возникающих общественных отношений, предполагаемой невозможности принять правотворческими органами тех решений, которые будут ждать от него адресаты действующих правовых предписаний.

\section{Библиография:}

1. Конституция Российской Федерации. 12 декабря 1993г.

2. Федеральный Конституционный Закон 2002г. N 1-ФКЗ «О военном положении» // Собрание законодательства РФ. 2002. N 5. ст. 375.

3. Федеральный закон 1996г. N 61-Ф3 «Об обороне» // Российская газета. 6 июня 1996г.

${ }^{23}$ Иоффе О.С. Правоотношение по советскому гражданскому праву. Л., 1949. С. 81. 
DOI: $10.7256 / 1811-9018.2015 .8 .12562$

При цитировании этой статьи сноска на dоі обязательна

Человек и государство

4. Федеральный закон 1998г. N 53-Ф3 «О воинской обязанности и военной службе» // Собрание Законодательства РФ. 1998. № 13. Ст. 1475.

5. Федеральный закон 1997 г. N 31-Ф3 «О мобилизационной подготовке и мобилизации в Российской Федерации» // Российская газета. 5 марта 1997г.

6. Беломестных Л.Л. Ограничение прав человека. М., 2003.

7. Гражданское право: Учебник. В 2-х т. Т. 1 / Под ред. Е.А. Суханова. М., 1993.

8. Гражданское право: Учебник. В 2-х т. Т. 1 / Под ред. Ю.К. Толстого, А.П. Сергеева. СПб. 1996.

9. Дудин А.П. Объект правоотношения (вопросы теории). Саратов, 1980.

10. Домрин А.Н. Правовые институты чрезвычайного режима в Великобритании.//Зарубежное законодательство. 1996. № 15-16.

11. Ильин И.Л. О сущности правосознания. М., 1993.

12. Иоффе О.С. Правоотношение по советскому гражданскому праву. Л., 1949.

13. Касаткина Н.М., Лафитский В.И. Правовые институты чрезвычайного режима в США // Право и политика.1996. №12.

14. Квитко А.Ф. Конституционно-правовые основы ограничения прав и свобод человека и гражданина в Российской Федерации. Автореф. дис.... канд. юрид. наук. М., 2007.

15. Лопаева В.В. Проблема ограничения прав и свобод человека и гражданина в конституции Российской Федерации // Журнал российского права. 2005. № 7.

16. Малько А.В. Стимулы и ограничения в праве. М., 2003.

17. Марченко М.Н. Проблемы теории государства и права. М., 2001.

18. Пилипенко А.Н. Институты чрезвычайного режима во Франции // Право и экономика. 2007. №7-8.

19. Приказы народного комиссара обороны СССР. 1943 - 1945гг. М.: Терра, 1997. Т. 13.

20. Принципы, пределы, основания ограничения прав и свобод человека по российскому законодательству и международному праву: Материалы «круглого стола» // Государство и право. 1998. №№ 7,8,10.

21. Пчелинцев С.В. Проблемы ограничения прав и свобод граждан в условиях особых правовых режимов. М., Норма, 2006.

22. Халфина Р.О. Общее учение о правоотношении. М, 1974.

23. Х Хропанюк В.Н. Теория государства и права. М., 1995.

24. Цицероп. Об обязанностях. СПб. 1903.

25. Шершеневич Г.Ф. Общая теория права. Вып. III. 1910.

26. Эбзеев Б.С. Человек, народ, государство в конституционном строе Российской Федерации. М., 2005.

27. Ягофарова И.Д. Основные характеристики ограничения прав и свобод человека: теоретико-правовой аспект // Академический юридический журнал. 2002. № 4.

28. Дубынина Т.В.. Об исторической взаимосвязи военного права и гражданского права России // Национальная безопасность / nota bene. - 2014. - № 3. - C. 104-107. DOI: 10.7256/2073-8560.2014.3.11894

29. Олейникова Е.Г. Социальная ситуация в Сталинграде в период Великой Отечественной войны и послевоенного восстановления // NB: Исторические исследования. - 2013. - № 6. - C.106-124. DOI: 10.7256/2306-420X.2013.6.9492. URL: http://e-notabene.ru/hr/article_9492.html

30. Разумов Ю.А. Некоторые конституционно-правовоые особенности реализации норм международного права в военной сфере в зарубежных странах // NB: Международное право. - 2013. - № 1. - C.171-183. DOI: 10.7256/2306-9899.2013.1.684. URL: http://e-notabene.ru/wl/article_684.html

31. Слезин А.А., Пузырев А.Ю. Военная пропаганда в провинции 1930-х годов как инструмент защиты национальной безопасности ССCP // NB: Национальная безопасность. - 2012. - № 2. - C.153-187. DOI: 10.7256/2306-0417.2012.2.264. URL: http://e-notabene.ru/nb/article_264.html

32. Сергунин А.А. Концепт «Военная безопасность» и эволюция военно-политического мышления постсоветской России // NB: Национальная безопасность. - 2012. - № 2. - C.119-140. DOI: 10.7256/2306-0417.2012.2.183. URL: http://e-notabene. ru/nb/article_183.html

33. Земсков В.Н... Начальный этап репатриации советских военнопленных и интернированных гражданских лиц (вторая половина 1944 г.) // Международные отношения. - 2014. - № 2. - C. 104-107. DOI: 10.7256/2305-560X.2014.2.10749

34. Дубынина Т.В.. Гражданско-правовой аспект военного права: некоторые вопросы теории // Право и политика. - 2014. - № 3. - C. 104-107. DOI: 10.7256/1811-9018.2014.3.1110

35. Владимирова Т.В. О значении новых мобильностей для безопасности // NB: Национальная безопасность. - $2014 .-1$. - C. 9 - 23. DOI: 10.7256/2306-0417.2014.1.11164. URL: http://www.e-notabene.ru/nb/article_11164.html

36. Редкоус В.М., Кулишов Д.Н. Административно-правовое положение граждан Российской Федерации в об- ласти обеспечения национальной безопасности: теоретические подходы к выработке понятия и опреде- лению структуры // Административное и муниципальное право. - 2013. - 10. - C. 931 - 943. DOI: 10.7256/1999-2807.2013.10.9651.

\section{References (transliterated):}

1. Belomestnykh L.L. Ogranichenie prav cheloveka. M., 2003.

2. Dudin A.P. Ob"'ekt pravootnosheniya (voprosy teorii). Saratov, 1980. 
DOI: $10.7256 / 1811-9018.2015 .8 .12562$

При цитировании этой статьи сноска на dоі обязательна

\section{Право и политика 8 (188) $\bullet 2015$}

3. Domrin A.N. Pravovye instituty chrezvychainogo rezhima v Velikobritanii.//Zarubezhnoe zakonodatel’stvo. 1996. № 15-16.

4. Il'in I.L. O sushchnosti pravosoznaniya. M., 1993.

5. Ioffe O.S. Pravootnoshenie po sovetskomu grazhdanskomu pravu. L., 1949.

6. Kasatkina N.M., Lafitskii V.I. Pravovye instituty chrezvychainogo rezhima v SShA // Pravo i politika.1996. №12.

7. Kvitko A.F. Konstitutsionno-pravovye osnovy ogranicheniya prav i svobod cheloveka i grazhdanina v Rossiiskoi Federatsii. Avtoref. dis.... kand. yurid. nauk. M., 2007.

8. Lopaeva V.V. Problema ogranicheniya prav i svobod cheloveka i grazhdanina v konstitutsii Rossiiskoi Federatsii //Zhurnal rossiiskogo prava. 2005. № 7.

9. Mal'ko A.V. Stimuly i ogranicheniya v prave. M., 2003.

10. Marchenko M.N. Problemy teorii gosudarstva i prava. M., 2001.

11. Pilipenko A.N. Instituty chrezvychainogo rezhima vo Frantsii // Pravo i ekonomika. 2007. №7-8.

12. Pchelintsev S.V. Problemy ogranicheniya prav i svobod grazhdan v usloviyakh osobykh pravovykh rezhimov. M., Norma, 2006.

13. Khalfina P.O. Obshchee uchenie o pravootnoshenii. M, 1974.

14. Khropanyuk V.N. Teoriya gosudarstva i prava. M., 1995.

15. Tsitserop. Ob obyazannostyakh. SPb. 1903.

16. Shershenevich G.F. Obshchaya teoriya prava. Vyp. III. 1910.

17. Ebzeev B.S. Chelovek, narod, gosudarstvo v konstitutsionnom stroe Rossiiskoi Federatsii. M., 2005.

18. Yagofarova I.D. Osnovnye kharakteristiki ogranicheniya prav i svobod cheloveka: teoretiko-pravovoi aspekt // Akademicheskii yuridicheskii zhurnal. 2002. № 4.

19. Dubynina T.V.. Ob istoricheskoi vzaimosvyazi voennogo prava i grazhdanskogo prava Rossii // Natsional'naya bezopasnost' / nota bene. - 2014. - № 3. - S. 104-107. DOI: 10.7256/2073-8560.2014.3.11894

20. Oleinikova E.G. Sotsial'naya situatsiya v Stalingrade v period Velikoi Otechestvennoi voiny i poslevoennogo vosstanovleniya // NB: Istoricheskie issledovaniya. - 2013. - № 6. - S.106-124. DOI: 10.7256/2306-420X.2013.6.9492. URL: http://e-notabene.ru/ hr/article_9492.html

21. Razumov Yu.A. Nekotorye konstitutsionno-pravovoye osobennosti realizatsii norm mezhdunarodnogo prava v voennoi sfere $\mathrm{v}$ zarubezhnykh stranakh // NB: Mezhdunarodnoe pravo. - 2013. - № 1. - S.171-183. DOI: 10.7256/2306-9899.2013.1.684. URL: http://e-notabene.ru/wl/article_684.html

22. Slezin A.A., Puzyrev A.Yu. Voennaya propaganda v provintsii 1930-kh godov kak instrument zashchity natsional'noi bezopasnosti SSSR // NB: Natsional'naya bezopasnost'. -2012. - № 2. - S.153-187. DOI: 10.7256/2306-0417.2012.2.264. URL: http://e-notabene. $\mathrm{ru} / \mathrm{nb} / \mathrm{article} 264 . \mathrm{html}$

23. Sergunin A.A. Kontsept «Voennaya bezopasnost”» i evolyutsiya voenno-politicheskogo myshleniya postsovetskoi Rossii // NB: Natsional'naya bezopasnost'. - 2012. - № 2. - S.119-140. DOI: 10.7256/2306-0417.2012.2.183. URL: http://e-notabene.ru/nb/ article_183.html

24. Zemskov V.N.. Nachal'nyi etap repatriatsii sovetskikh voennoplennykh i internirovannykh grazhdanskikh lits (vtoraya polovina 1944 g.) // Mezhdunarodnye otnosheniya. - 2014. - № 2. - S. 104-107. DOI: 10.7256/2305-560X.2014.2.10749

25. Dubynina T.V.. Grazhdansko-pravovoi aspekt voennogo prava: nekotorye voprosy teorii // Pravo i politika. - 2014. - № 3. S. 104-107. DOI: 10.7256/1811-9018.2014.3.1110

26. Vladimirova T.V. O znachenii novykh mobil'nostei dlya bezopasnosti // NB: Natsional'naya bezopasnost'. - 2014. - 1. - C. 9 - 23. DOI: 10.7256/2306-0417.2014.1.11164. URL: http://www.e-notabene.ru/nb/article_11164.html

27. Redkous V.M., Kulishov D.N. Administrativno-pravovoe polozhenie grazhdan Rossiiskoi Federatsii v ob-lasti obespecheniya natsional'noi bezopasnosti: teoreticheskie podkhody k vyrabotke ponyatiya i oprede- leniyu struktury // Administrativnoe i munitsipal'noe pravo. - 2013. - 10. - C. 931 - 943. DOI: 10.7256/1999-2807.2013.10.9651. 